RACAR : Revue d'art canadienne

Canadian Art Review

RACAR

\title{
Eve Borsook, The Mural Painters of Tuscany. Second edition, revised and enlarged. Oxford, Oxford University Press, 1980. 80 figs., 156 pl., 55,00 £.
}

\section{Barbara Dodge}

Volume 10, numéro 1, 1983

URI : https://id.erudit.org/iderudit/1074647ar

DOI : https://doi.org/10.7202/1074647ar

Aller au sommaire du numéro

\section{Éditeur(s)}

UAAC-AAUC (University Art Association of Canada | Association d'art des universités du Canada)

\section{ISSN}

0315-9906 (imprimé)

1918-4778 (numérique)

Découvrir la revue

Citer ce compte rendu

Dodge, B. (1983). Compte rendu de [Eve Borsook, The Mural Painters of Tuscany. Second edition, revised and enlarged. Oxford, Oxford University Press, 1980. 80 figs., 156 pl., 55,00 £.] RACAR : Revue d'art canadienne / Canadian Art Review, 10(1), 102-103. https://doi.org/10.7202/1074647ar

Tous droits réservés @ UAAC-AAUC (University Art Association of Canada | Association d'art des universités du Canada), 1983
Ce document est protégé par la loi sur le droit d'auteur. L'utilisation des services d'Érudit (y compris la reproduction) est assujettie à sa politique d'utilisation que vous pouvez consulter en ligne.

https://apropos.erudit.org/fr/usagers/politique-dutilisation/ 
de l'université Laval. Deux importants fonds, notamment, n'y sont pas répertoriés: le fonds Sylvio Brassard (environ 1500 plans, originaux et fac-similés) et la collection Cardwell-Ross Anderson (environ 1 ooo relevés et photographies).

La ville de Québec a délivré son premier permis de construction en mai 1913. L'Inventaire des permis de construction des archives de la ville de Québec, 1913-1930 répertorie 6755 permis, sélectionnés parmi les quelque 1 jooo émis au cours de cette période. L'auteur a retenu "les permis qui annonçaient les constructions nouvelles et les réparations majeures ou mineures qui avaient une incidence directe sur la lecture d'un édifice" (p. 8); les réparations mineures ont été rejetées, de même que la construction de hangars, d'écuries et de poulaillers, à moins qu'ils n'aient été de brique.

Les permis ont été classés par ordre alphabétique de lieux, puis par ordre chronologique. Chaque entrée fournit les informations suivantes: référence, date, nom du propriétaire, description des travaux prévus, adresse, coût des travaux, noms de l'architecte et des constructeurs. Dans les cas d'adresse incomplète, l'auteur a ajouté entre parenthèses les numéros civique et/ou cadastral; ces numéros civiques, utilisés à l'époque de l'émission du permis, ont généralement été changés depuis, sauf dans l'arondissement historique du Vieux-Québec. L'existence de plans ou de devis, parfois présentés avec la demande de permis et ensuite conservés aux archives de la ville, n'est pas toujours consignée. Un index des noms (personnes, compagnies et institutions) et un index des lieux complètent le catalogue.

Dans l'Inventaire des marchés de construction des Archives nationales $d u$ Québec à Montréal, I 800-1830, 2101 actes notariés ont été compilés. Ils proviennent des greffes de quelque 45 notaires actifs dans la région de Montréal, mais parfois aussi ailleurs dans la province, par exemple à Québec ou à Trois-Rivières. D'ailleurs, les marchés de construction inventoriés concernent principalement la région montréalaise, mais s'étendent aussi à Trois-Rivières, à Québec, et même au Bic et à "York. au Haut-Canada".
Chaque entrée donne le nom du notaire, les noms des contractants, la ville et la date où fut signé le contrat, le numéro de celui-ci et, cnfin, unc description des travaux faisant l'objet du marché. La classification cst d'abord basée sur les noms de lieux, puis, occasionnellemont, sur les types d'édifices (religieux, publics, ctc.) et, enfin, sur les dates des contrats. I a classification par licux respecte rigoureusement l'ordre alphabétique des toponymes anciens tels qu'utilisés dans les contrats, et sans aucune hiérarchie. Ainsi, les lieux "Faubourg SaintLaurent", "Montréal" et "Rue Bleury" sont classés respectivement dans les $\mathrm{F}$, les $\mathrm{M}$ et les $\mathrm{R}$, sans tenir compte de leur interpénétration, et sont placés en ordre alphabétique avec des toponymes vagues comme "Prc̀s dc la ville" ou "Marché à foin". Aucunc table de concordance des toponymes anciens et actuels n'ayant été incluse, cette classification n'est guère accessible qu'aux seuls spécialistes en topographie ancienne.

Les index, un premier pour les noms des contractants et un deuxic̀mc pour les toponymes, les types d'édifices et les noms d'édifices importants, auraient gagné à suivre la mise en page des inventaires déjà parus. En effet, dans ce cas-ci, l'utilisation systématique des lettres majusculcs pour les noms, prénoms ct toponymes rend la lecture plutôt malaiséc, alors que l'emploi trop fréquent d'un large espacement gonfle inutilement le nombre de pages alloué aux index.

L'cnsemble des inventaires publićs par Parcs Canada constitue certes un instrument de recherche fort utile: d'une part, ils permettent de retracer sans trop de difficulté des informations autrefois presque inaccessibles parce que non indexées, ct d'autre part, ils facilitent l'accès aux documents originaux auprès des services d'archives intéressćs. I a formule normalisée suivant laquelle ces inventaires sont construits s'avère efficace. Toutefois, cn ce qui a trait à la présentation, il cst dommage que les titres des sections n'aient pas été rappelés cn haut de chaque page, comme dans un dictionnaire, ce qui aurait facilité la consultation. De plus, il aurait peut-être été avantageux de réduire le format du textc, sans perte de lisibilité, afin de rendrc ces ouvrages moins volumineux.

PIERRF: I.ANI)RY Archives publiques du Cianada

EVE BORSOOK The Mural Painters of Tuscany. Second edition, revised and enlarged. Oxford, ()xford Lniversity Press, 1980.80 figs., 156 pl., 55,00£.

The publication in 1960 of Eve Borsook's Mural Painters of Tuscany gave students of Italian art an informative, richly illustrated discussion of the great tradition of late mediaeval and Renaissance wall paintings. Especially noteworthy were the author's discussions of mural techniques and the relationship between wall paintings and their architectural settings (handsomely illustrated with many views of the works in situ).

The ensuing two decades have witnessed a tremendous growth in understanding of fresco paintings of the late thirteenth to the carly sixteenth centuries. The poor condition of many mural paintings, due particularly to the 1966 flood in Florence, led to restoration campaigns which have produced much new information on the preparation and execution of thesc works, as well as techniques for detaching and conserving them. 'Thesc findings have been presented in exhibitions of detached frescoes and sinopie, notably the Great Age of Fresco circulated in Europc and the United States in 1968, Firenze Restaura and Metodo e Scienza (1972 and 1982 respectively), tributcs to the achievements of the restoration laboratories of the Sopraintendenza in Florence. Concurrently, art historians have researched the themes and histories of fresco works by Tuscan artists.

A second edition of The Mural Painters of Tuscany is therefore timely, and Dr. Borsook has superbly revised her text. Using the same format as the first edition - an introductory essay on the history and techniques of Tuscan mural painting followed by a detailed catalogue of individual works - Dr. Borsook incorporates the lindings 
of recent literature and restoration campaigns. Much of the information reflects her own work in the archives, libraries and buildings of Tuscany and her close connections with the équipes of Ieonetto Tintori, Giuseppe Rosi, Alfio del Serra and others. Many new splendid photographs have been added thanks to the efforts of photographers from the Gabinetto Fotografico of the Florentine Sopraintendenza and the Kunsthistorisches Institut.

Dr. Borsook's introduction remains an excellent, lucid summary of the origins and evolution of mural paintings by Tuscan artists. She outlines the social and cultural context of the development of a tradition of extensive mural decoration in religious and secular settings, contrasts developments in Florence and Siena, and analyses the bonds between images and sites. Much attention is given to the history of mural techniques, including the evolution of preparatory methods. In the Trecento, sinopie, probably often in conjunction with small scale drawings, allowed the fresco painter to explore the problems which confronted him and prepare his works. In the fifteenth century, the demands of new developments in iconography, perspective and the depiction of the human form, nccessitated a more complex developmental process for composing and transferring images to the wall. Preparation in small scale drawings became increasingly important, and sinopie were gradually replaced by cartoons.

The significance of the evidence from recent restoration campaigns is clear in Dr. Borsook's technical discussions. Detailed information is given on technical matters such as pigments used by fresco painters and the ways artists attempted to slow the carbonation of plaster. Individual artists' techniques, notably Simone Martini and Domenico Ghirlandaio, are analysed in greater detail than in the first edition. There is an expanded discussion on small scale drawings, as studies, copies and modelli, in relation to fourteenth-century mural painting. Dr. Borsook could have argued more strongly that small scale drawings were used fairly regularly and often in conjunction with sinopie in the preparation of mural paintings in the Trecento given the evidence put forth in the last twenty years to support this conclusion.
One of the other tantalizing questions regarding mural technique is the early use of cartoons, and Dr. Borsook adds new examples of the use of cartoons, transferred by pouncing and possibly by incisions, in fourteenth-century works.

The most significant revisions in the second edition are found in the catalogue. More recent information is added to previous entries, and scveral new works are added, notably the Magdalen Chapcl by an anonymous follower of Giotto in the lower church of S. Francesco, Assisi, the Chapel of the Assumption by the Prato Mastcr in the Cathedral of Prato, and the Assumption of the Virgin in $\mathrm{S}$. Niccolò Oltrarno by a follower of Andrea del Castagno. Fach entry is identified by artists, subject, date and measurements, followed by discussions of history, scheme, technique and condition. Bibliographic information is contained within extensive notes appended to each entry.

I he entries report documentary evidence, discuss patronage, the formulation of the schemes, and iconographic sources. The tcchnical information is again one of the most original and significant contributions. Painting in buon fresco, $\sec (0)$ and variants are identified, scalfolding, pigments, giornate, pentimenti, and preparation by sinopie or cartoons are considered. The history of past restoration campaigns and the present state of condition are identificd. Sadly, many works arc still in precarious condition, and further intervention is desperately needed. Despite recent restoration campaigns. Simone Martini's Mastì in Siena and Piero della Francesca's Story of the True Cross in Are7.7.) are among the masterpieces whose continued existence is still in jeopardy.

The following examples can only hint at the divcrsity and richness of material to be found in the author's catalogue. The descriptions of individual artists' techniques arc superb and are particularly informative when they include hitherto unpublished results from recent conservation campaigns. Among these are Simone Martini's Montefiore Chapel in Assisi and the cycle by the Prato Master in the Prato Cathedral. Dr. Borsook has written previously on the Prato cycle, and she and Johannes Offerhaus have recently published on Ghirlandaio's
Sassetti Chapel in S. Trinita, Florence. On the latter, Dr. Borsook provides a summary of their findings on the technique and interpretation of the themes. Her presentations of cycles such as Giotto's Arena Chapcl and Masaccio's Bran(acci Chapcl are excellent summaries of the current state of rescarch.

While therc are many cycles and works one would wish to see included such as Ciotto's chapels in S. Croce or Pontormo's works from the Certosa or Poggio a Caiano, we must be thankful to Dr. Borsook and her cditors for this handsome, informative new edition. The general student of Italian art will find a superb introduction to the fascinating history of mural paintings in the late Middle Ages and Renaissance, whilc the catalogue will offer much detailed material for the specialist to consult.

BARBARA DODGE. York University

JOIIN RUSKIN Les sept lampes de l'architecture, illustré de dessins de l'auteur (trad. par (. Elwall), suivi de John Ruskin, par Marcel Proust. Paris, I.es Presses d'aujourd'hui, 1980. (L'arbre double) $252+$ viii p., 14 pl., $12,80 \$$ (relié).

La traduction de l'œuvre de John Ruskin présentée par les Presses d'aujourd'hui nous ramène à un substrat idćologique fort différent du nôtre. C'est précisément la désuétude de la pensée et de l'expression qui fait l'intérêt des Sept lampes pour le lecteur rompu à une autre dialectique. En un temps où le post-modernisme retient les chercheurs, en un temps où un nouvel investissement symbolique est souhaité après un bon demi-siècle de fonctionnalisme, le discours de référence mystico-littéraire de Ruskin et sa charge passionnelle acquièrent un curieux relief. Non moins d'aillcurs que l'essai consacré par Marcel Proust à Ruskin, dont nous rendons également compte dans ces colonnes.

La première édition de l'œuvrc du sociologue et critique d'art date de 1849. Cependant, en 1880 , son auteur jugea bon de rectifier certains passages qui ne convenaient 